\title{
МОЛЕКУЛЯРНО-ГЕНЕТИЧЕСКАЯ ИДЕНТИФИКАЦИЯ ТОКСИНООБРАЗУЮЩИХ ФИТОПАТОГЕНОВ ИЗ РОДОВ FUSARIUМ И PENICILLIUM НА ОЗИМОЙ ПШЕНИЦЕ
}

\author{
Игнатова 3., Кузнеиова И. \\ Институт Генетики, Физиологии и Защиты Растений \\ e-mail: zoianciki@mail.ru
}

\begin{abstract}
The aim of the study was the molecular-genetic identification (nested-PCR analysis) of pathogens from genera Fusarium and Penicillium, which are dangerous to human and animal health, in the winter wheat. As a result, species from both genera were detected in the winter wheat at different stages of plants development. The most important was the fact that these pathogens were detected in mature seeds. This can present a potential danger of contamination of food raw material with mycotoxins produced by identified fungi. Additionally, the influence of climatic conditions of the year to the spread of tested pathogens was established.

Keywords: pathogen detection, mycotoxin producers, Fusarium genus, Penicillium species, nested-PCR, winter wheat

$\begin{array}{cccc}\text { Проблемение } & & \\ \text { Пронтаминации } & \text { микотоксинами продовольственных } \quad \text { продуктов, }\end{array}$ производимых из зерновых культур, стоит очень остро, так как в настоящее время нет эффективных способов их обезвреживания $[1,3,4]$. По некоторым данным, почти четверть всего урожая зерновых поражена микотоксинами $[2,5]$. В целях безопасности продовольственного сырья необходим своевременный контроль путем идентификации фитопатогенов - продуцентов ядовитых метаболитов. В этой связи весьма актуальна молекулярно-генетическая идентификация опасных для здоровья человека и животных патогенов методом ПЦР, что позволяет быстро и надежно выявлять наличие определенных видов грибов в растениях еще на стадии вегетации, до сбора урожая.
\end{abstract}

\section{Материалы и методы}

Анализ растительной ДНК на присутствие патогенных грибов, синтезирующих ядовитые метаболиты, проводился с использованием метода nested-PCR. Тестировались растения озимой пшеницы, выращиваемые на опытном участке ИГФЗР. Растительный материал из разных тканей отбирали для молекулярного анализа на соответствующих фазах вегетации: корень и корневая шейка (GS-33), зачатки колоса в трубке на ранней стадии развития (GS-33), колос в трубке перед выколашиванием (GS-45), колос в начале колошения (GS-55), колос в начале цветения (GS-61), колос в конце цветения (GS-69), зерно с колосовыми чешуйками в стадии ранней молочной спелости (GS-83), зрелые семена (GS-93).

ДНК из разных растительных тканей экстрагировали по СТАВ-протоколу с модификациями. 
Для идентификации патогенов видов Fusarium oxysporum, F. verticillioides, F. avenaceum, F. equiseti, F. incarnatum, Penicillium chrysogenum и Р. expansum были использованы специфичные праймеры, сконструированные в лаборатории молекулярной генетики ИФГЗР.

ПЦР проводилась в два раунда (nested-PCR). Реакционная смесь объемом 25 мкл содержала: $66 \mathrm{mM}$ трис-HCl (pH-8,4), $16 \mathrm{mM}\left(\mathrm{NH}_{4}\right)_{2} \mathrm{SO}_{4}, 2,5 \mathrm{mM} \mathrm{MgCl}_{2}, 0,1 \%$ Tween 20, 7 \% глицерина, 100 мкг/мл BSA (Bovin Serum Albumin), по 0,2 mM каждого из dNTP, 2 единицы Таq-полимеразы, 5 pM праймера и 20 нг ДНК. В обоих раундах соблюдался следующий режим: денатурация при $95{ }^{\circ} \mathrm{C}\left(1\right.$ мин), отжиг при $60{ }^{\circ} \mathrm{C}(1$ мин.), элонгация при $72{ }^{\circ} \mathrm{C}$ (1 мин.). Число циклов как в первом, так и во втором раундах -30 .

Продукты амплификации анализировали электрофорезом в 1,5 \%-ном агарозном геле, окрашивали бромистым этидием и визуализировали в ультрафиолете (312 нм). В качестве молекулярного маркера использовался 100 bp DNA ladder фирмы Thermo Fisher Scientific.

\section{Результаты и обсуждение}

Образцы ДНК, экстрагированные из разных органов растений пшеницы (сезон вегетации 2018 года) на изучаемых стадиях развития первоначально тестировали на наличие микромицетов рода Fusarium. Затем варианты с положительной реакцией на Fusarium spp. исследовали на видовой состав данного патогена. Результаты тестирования представлены в таблице 1.

Как видно из данных, представленных в таблице 1, ДНК патогена рода Fusarium присутствовала во всех образцах исследуемых растений. Использование праймеров, специфичных для соответствующих видов, позволило выявить Fusarium oxysporum и Fusarium avenaceum только в одном из четырех проанализированных вариантов. В остальных случаях виды Fusarium не были идентифицированы.

Таблица 1. Видовой состав патогенов рода Fusarium в различных органах растений озимой пшеницы в период вегетации 2018 года

\begin{tabular}{|l|c|c|c|c|}
\hline \multirow{2}{*}{ Патоген } & \multicolumn{4}{|c|}{ Органы и фазы развития озимой пшеницы } \\
\cline { 2 - 5 } & $\begin{array}{c}\text { Корневая } \\
\text { шейка (GS- } \\
33 \text { ) }\end{array}$ & $\begin{array}{c}\text { Колос, } \\
\text { конец } \\
\text { цветения } \\
\text { (GS-69) }\end{array}$ & $\begin{array}{c}\text { Колос, } \\
\text { восковая } \\
\text { спелость } \\
\text { (GS-77) }\end{array}$ & $\begin{array}{c}\text { Зерно, } \\
\text { созревание } \\
\text { (GS-97) }\end{array}$ \\
\hline Fusarium spp. & + & + & + & + \\
\hline Fusarium vertcillioides & + & + & + & + \\
\hline Fusarium oxysporum & + & - & - & - \\
\hline Fusarium avenaceum & - & - & - & + \\
\hline
\end{tabular}

Количественное распределение видов рода Fusarium, выявленных в растениях пшеницы, представлено на рисунке 1. 


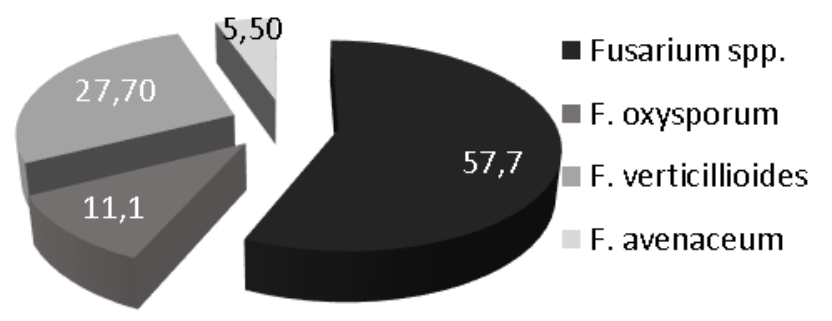

Рисунок 1. Распределение (\%) видов рода Fusarium, выявленных в растениях пшеницы (сезон вегетации 2018 года).

Учитывая, что в 2018 году проводилась идентификация только трех видов рода Fusarium, и два из них были представлены в проанализированных образцах в малом количестве, возникла необходимость расширения спектра специфичных праймеров для дальнейшей видовой идентификации.

В 2019 году образцы озимой пшеницы на разных этапах развития были протестированы методом nested-PCR для дополнительного выявления и идентификации других видов патогенов: Fusarium equiseti и Fusarium incarnatum. Кроме того, проводилось тестирование на присутствие в растительных образцах ДНК токсинообразующих грибов - Penicillium chrysogenum и P. expansum. Специфичные для данных видов праймеры также были сконструированы в лаборатории молекулярной генетики ИГФЗР. Дополнительно, при изучении заражения образцов пшеницы сезона вегетации 2019 года были использованы те же праймеры, специфичные к трем видам рода Fusarium, что и в исследованиях 2018 года. Полученные данные представленны в таблице 2.

Таблица 2. Видовой состав патогенов родов Реnicillium и Fusarium в различных органах растений озимой пшеницы в период вегетации 2019 года

\begin{tabular}{|c|c|c|c|c|c|c|}
\hline \multirow[b]{2}{*}{ Патоген } & \multicolumn{6}{|c|}{ Органы и фазы развития озимой пшеницы } \\
\hline & $\begin{array}{l}\text { Колос, } \\
\text { выход в } \\
\text { трубку }\end{array}$ & $\begin{array}{l}\text { Колос, } \\
\text { начало } \\
\text { колошения }\end{array}$ & $\begin{array}{l}\text { Колос, } \\
\text { начало } \\
\text { цветения }\end{array}$ & $\begin{array}{l}\text { Колос, } \\
\text { конец } \\
\text { цветения }\end{array}$ & $\begin{array}{l}\text { Зерно, } \\
\text { молочно- } \\
\text { восковая } \\
\text { спелость }\end{array}$ & $\begin{array}{l}\text { Зерно, } \\
\text { созревание }\end{array}$ \\
\hline $\begin{array}{l}\text { Penicillium } \\
\text { expansum }\end{array}$ & + & - & - & - & - & + \\
\hline $\begin{array}{l}\text { Penicillium } \\
\text { chrysogenum }\end{array}$ & + & - & - & + & + & + \\
\hline Fusarium spp. & - & + & + & + & + & + \\
\hline $\begin{array}{l}\text { Fusarium } \\
\text { verticillioides }\end{array}$ & - & - & - & - & - & - \\
\hline $\begin{array}{l}\text { Fusarium } \\
\text { oxysporum }\end{array}$ & - & - & - & + & - & - \\
\hline $\begin{array}{l}\text { Fusarium } \\
\text { avenaceum }\end{array}$ & - & - & + & - & - & - \\
\hline $\begin{array}{l}\text { Fusarium } \\
\text { equiseti }\end{array}$ & - & - & - & - & - & + \\
\hline $\begin{array}{l}\text { Fusarium } \\
\text { incarnatum }\end{array}$ & - & - & - & - & - & - \\
\hline
\end{tabular}


В результате ПЦР-анализа, проведенного с помощью специфичных праймеров, было выявлено, что ДНК видов Р. chrysogenum и Р. expansum присутствует в растительных образцах на стадиях «созревание» и «выход в трубку». На стадиях «конец цветения» и «молочно-восковая спелость» тестирование на присутствие исследуемых патогенов дало только один положительный результат: был выявлен P. chrysogenum.

Тестирование тотальной ДНК на наличие патогенов рода Fusarium spp. продемонстрировало положительный сигнал амплификации на всех изучаемых фазах развития, кроме фазы «выхода в трубку» (зачаток колоса). F. avenaceum и F. oxysporum были идентифицированы в единичных случаях на стадиях «начало цветения» и «конец цветения», соответственно. Представители вида F. equiseti были обнаружены только в образцах зрелых семян. ПЦР-диагностика со специфичными к $\mathrm{F}$. vertcillioides и $\mathrm{F}$. incarnatum праймерами показала полное отсутствие ДНК данных патогенов в исследуемых образцах.

\section{Выводы}

Молекулярно-генетическая диагностика озимой пшеницы выявила ее заражение патогенами родов Penicillium и Fusarium на разных стадиях развития растений.

Важным является результат, что оба исследованных вида рода Penicillium были идентифицированы в зрелом зерне озимой пшеницы, что указывает на потенциальную опасность контаминации продовольственного сырья микотоксинами, продуцируемыми данными патогенами. В то же время, Р. chrysogenum был обнаружен в растительном материале на четырех из шести изученных фаз развития, тогда как распространение $\mathrm{P}$. expansum было обнаружено только на двух фазах из шести.

Патогены рода Fusarium также были обнаружены в образцах зрелых зерен пшеницы урожаев 2018 и 2019 годов, что свидетельствует о потенциальной опасности наличия соответствующих микотоксинов в продовольственном сырье. Сравнивая результаты заражения озимой пшеницы в оба периоды вегетации, можно сделать вывод, что F. охуsporum обнаруживается на более ранних фазах развития растений и исчезает к моменту сбора урожая. При оценке продовольственной продукции некоторую опасность представляют F. vertcillioides и F. avenaceum, однако эти виды патогенов зависят от условий года: в зрелом зерне они выявлены только в урожае 2018 года, тогда как в сезоне вегетации 2019 года они почти не поражали растения пшеницы на разных стадиях развития растений включая созревшие зерна. В зрелых зернах сбора 2019 года был обнаружен только один представитель рода Fusarium - F. equiseti, который не был выявлен на более ранних стадиях периода вегетации пшеницы. И, наконец, F. incarnatum вообще не был идентифицирован в растениях озимой пшеницы в сезоне вегетации 2019 года.

\section{Библиография}

1. David J., Ting Z., Rong T., Massimo M. Mitigation of Patulin in Fresh and Processed Foods and Beverages. Toxins (Basel), 9 (5), 2017, pp. 1-18.

2. Frisvad J. C., Smedsgaard J., Larsen T. et al. Mycotoxins, drugs and other extrolites produced by species in Penicillium subgenus Penicillium. Studies in Mycology, 2004, 49, pp. 201-241.

3. Pose G., Patriarca A., Kyanko V. et al. Water activity and temperature effects on mycotoxin production by Alternaria alternata on a synthetic tomato medium. International Journal of Food Microbiology, 142 (3), 2010, pp. 348-353

4. Richard J. L. Some major mycotoxins and their mycotoxicoses-An overview. International Journal of Food Microbiology, 119, 2007, pp. 3-10. 
5. Монастырский О.А. Токсинообразующие грибы и микотоксины. Защита и карантин растений. Москва, 2006, 321 с. 